\title{
Perspectives on Reducing the
} National Milk Deficit and Accelerating the Transition to a
Sustainable Dairy Value Chain in
Zimbabwe

\begin{abstract}
Ngonidzashe Chirinda ${ }^{1 *}$, Chrispen Murungweni ${ }^{2}$, Addmore Waniwa ${ }^{3 *}$, Justice Nyamangara ${ }^{4}$, Aziza Tangi ${ }^{1}$, Michael Peters ${ }^{5}$, An Notenbaert ${ }^{5}$ and Stefan Burkart ${ }^{6}$

${ }^{1}$ AgroBioSciences, Agricultural Innovations and Technology Transfer Centre, Mohammed VI Polytechnic University (UM6P), Ben Guerir, Morocco, ${ }^{2}$ School of Agricultural Sciences and Technology, Chinhoyi University of Technology (CUT), Chinhoyi, Zimbabwe, ${ }^{3}$ Department of Veterinary Services, Ministry of Lands, Agriculture, Fisheries, Water and Rural Development, Harare, Zimbabwe, ${ }^{4}$ Department of Environmental Science and Technology, Marondera University of Agricultural Sciences and Technology (MUAST), Marondera, Zimbabwe, ${ }^{5}$ Crops for Nutrition and Health, Tropical Forages Program, Alliance Bioversity International and CIAT, Nairobi, Kenya, ${ }^{6}$ Crops for Nutrition and Health, Tropical Forages Program, Alliance Bioversity International and CIAT, Cali, Colombia
\end{abstract}

OPEN ACCESS

Edited by:

Rein Van Der Hoek, Alliance Bioversity International and CIAT, France

Reviewed by:

Helene Lie,

Norges Vel, Norway

Heinrich Hagel,

University of Hohenheim, Germany

*Correspondence: Ngonidzashe Chirinda Ngonidzashe.Chirinda@um6p.ma

Addmore Waniwa waniwaa@gmail.com

Specialty section:

This article was submitted to Climate-Smart Food Systems, a section of the journal

Frontiers in Sustainable Food Systems

Received: 16 June 2021 Accepted: 10 November 2021 Published: 02 December 2021

Citation:

Chirinda N, Murungweni C, Waniwa A Nyamangara J, Tangi A, Peters $M$, Notenbaert A and Burkart S (2021)

Perspectives on Reducing the National Milk Deficit and Accelerating the Transition to a Sustainable Dairy Value Chain in Zimbabwe. Front. Sustain. Food Syst. 5:726482. doi: 10.3389/fsufs.2021.726482
The Zimbabwean dairy industry is massively underperforming, as evidenced by a reduction in milk yield from 262 million liters in 1990 to $<37$ million liters in 2009 and a steady but slow increase to 82 million liters in 2021. The current demand for milk in Zimbabwe stands at 130 million liters, and there is a national capacity for processing 400 million liters per annum. This study used literature, stakeholder inputs and expert knowledge to provide a perspective on practical options to reduce the national milk deficit and, simultaneously, accelerate the transition to a sustainable dairy value chain in Zimbabwe. Following a discussion on the key barriers and constraints to developing the milk value chain, we explored opportunities to improve the performance of the underperforming smallholder and medium-scale dairy farmers. Specifically, we discussed innovative management, creative policy instruments and alternative technological options to maximize milk production in Zimbabwe. We also highlight the need for an inclusive and creatively organized dairy value chain to optimize stakeholder linkages and improve information flow and equity. Examples of crucial investments and incentive structures for upgrading the existing value chain and monitoring greenhouse gas emissions and carbon uptake are discussed. Furthermore, the socio-economic effects (i.e., profitability, women empowerment and employment creation), milk quality, safety and traceability issues linked to a better organized and performing dairy value chain are highlighted.

Keywords: greenhouse gas emissions, gender roles, employment creation, innovation, policy, milk productivity

\section{INTRODUCTION}

The agricultural sector in Zimbabwe supports the livelihoods of approximately $70 \%$ of the population and contributes approximately 17\% of GDP (FAO, 2021). In a baseline survey conducted by Transforming Zimbabwe's Dairy Value Chain for the Future Action (TranZ DVC) (2019), income from milk and milk by-products were reported to contribute only $0.3 \%$ of the total GDP, and the milk processing component of the 
dairy value chain was reported to employ 282 male and 86 female youth ( $<35$ years). Moreover, of the total number of jobs that offer a fair income and social protection (descent jobs), along the dairy value-chain, $39.5 \%$ and $23 \%$ were reported to be held by women and youth, respectively (Transforming Zimbabwe's Dairy Value Chain for the Future Action (TranZ DVC), 2019).

From the mid-90s, the dairy cattle herd decreased due to recurrent droughts, economic contraction, and the land reform programme that disrupted large-scale dairy operations responsible for $>95 \%$ of the national milk pool (Kagoro and Chatiza, 2012). The land reform programme, which involved redistributing land from the large-scale commercial sector to households from the overcrowded communal areas, and the resultant lack of clarity in the security of land tenure were probably the most important factors that negatively impacted the dairy sector (Mzumara, 2012; Marecha, 2013). The difficult operational conditions created by the factors mentioned above resulted in a decrease in the number of registered commercial dairy farmers from 559 in 1987 to 165 in 2012 (SNV, 2012). Over the same period, 1987-2012, the dairy herd decreased from 113,006 to 27,400 resulting in the underperformance of the value chain, as evidenced by a reduction in milk yield from 262 million liters in 1990 to $<37$ million liters in 2009 (Dairy Services, 2020).

Although recent public and private sector interventions contributed to a steady but slow increase in annual national milk outputs, which stood at 80 million liters in 2019 (Dairy Services, 2020), these are below the national capacity for milk consumption which is 130 million and the capacity for the processing which is 400 million liters per annum (Ministry of Lands, Agriculture and Rural Resettlement, 2016). Since national milk demand stands at 130 million liters (Dairy Services, 2020), milk deficits are covered by importing milk and dairy products (TrendEconomy, 2020). Meeting this demand through local production instead of imports presents an opportunity to improve the welfare of producers and support sectors through increased income and employment generated along the value chain. This perspective article is aimed at exploring practical options for reducing Zimbabwe's milk deficit by improving the performance of smallholder $(<200$ liters per farm per day) and medium-scale (200-500 liters perfarm per day) dairy farmers. To achieve this objective, in early 2021, we reviewed existing literature (e.g., scientific articles, databases, gray literature) and sought inputs from key stakeholders and experts with knowledge on the dairy value chain in Zimbabwe (most of them involved as co-authors). With these inputs, we provide our perspective on (i) how milk production is organized in Zimbabwe, (ii) where and how milk is being processed and marketed, (iii) who the key stakeholders along the dairy value chain are, (iv) what the environmental impacts of dairy production are, and (v) the barriers and constraints for improving the performance of the dairy value chain. Based on this, we then provide a discussion where we suggest key interventions that could help improve the dairy value chain performance and improve the livelihoods of various value chain actors.

\section{MILK PRODUCTION REGIONS AND PRODUCTION SYSTEMS}

Zimbabwe is divided into five agro-ecological regions (AER) based on the amount of received rainfall. Large-scale commercial dairy production is mainly conducted in AER I $(>1,000 \mathrm{~mm}$, 1,100-2,600 masl), AER IIA and IIB (750-1,000 mm, 1,100$1,800 \mathrm{masl})$, AER III (650-800 mm, 1,100-1,200 m) [Marongwe et al., 1998; FAO, 2006a; Government of Zimbabwe (GoZ), 2013]. Mean annual temperatures in areas supporting large-scale dairy production range between $15-18^{\circ} \mathrm{C}, 16-19^{\circ} \mathrm{C}$ and $18-$ $22^{\circ} \mathrm{C}$ in AER I, II and III, respectively (Mugandani et al., 2012). Smallholder dairy farmers are located in all AER, including the dry regions ( $<650 \mathrm{~mm}$ annual rainfall), AER IV (600-1,200 masl) and AER V (300-900 masl). A visual representation of the spatial distribution of the AERs is given by Kashagura (2014).

Smallholder farmers, with an average of three cows per farmer, generally practice dairying for household consumption and sales of excess production to informal markets (Kagoro and Chatiza, 2012). While milk production levels vary between different farms, low milk yields ( $<200$ liters per farm per day) in the smallholder sector contribute to their small share of the national milk pool ( 2-3\%) (Hanyani-Mlambo, 2000; Munangi, 2007). Therefore, while smallholder production is essential for food security, low milk yields partly due to reliance on low-yielding local breeds and cross-breeds (4-6 L per cow per day) result in their contribution to the national milk pool being largely invisible (Chinogaramombe et al., 2008; SNV, 2012). The contribution of medium-scale farmers (200-500 L per farm per day) to the national milk pool is variable as some of these farmers have a large number of animals with low milk productivity. This variability in production levels was one of the reasons that led to dairy farmers now being classified based on total milk yields per day rather than cattle numbers. Currently, natural grasslands and crop residues are the primary feed resources used by smallholder and medium-scale dairy producers (Gwiriri et al., 2016). Consequently, the low milk yields experienced in the smallholder and some medium-scale farms are partially due to low yielding cattle breeds, seasonality in the availability of quality and adequate feed resources (Ngongoni et al., 2006).

Large-scale commercial dairy producers ( $>500 \mathrm{~L}$ per farm per day) that contribute to $>95 \%$ of the national milk pool are primarily located in AERs receiving relatively high $(>650 \mathrm{~mm})$ rainfall and relatively high (>1100 masl) altitude. The large dairy producers mainly use pure exotic cattle breeds (e.g., HolsteinFriesian breeds, Red Dane, Jersey, Guernsey), with a productivity range of 14-25 liters per cow per day (Mandiwanza, 2007; Matekenya, 2016). Besides high yielding cattle breeds, the high productivity of cattle in the large-scale producers is partially due to access to extensive grazing areas and financial resources to buy supplementary stock feeds during dry periods (Matekenya, 2016).

\section{MILK MARKETS}

Viable markets are crucial for incentivizing the increased competitiveness of any commercial enterprise. A major challenge 
that needs to be tackled in the dairy sector is that smallholder and medium-scale farmers ( $<500 \mathrm{~L}$ per day) are underperforming, thus not significantly contributing to the national milk pool. There are milk collection centers (MCCs) strategically located in the milk-producing regions for easy access to dairy farmers. Farmers deliver their milk to these centers, where it is tested for quality before being added into bulk milk tanks. In 2020, 17 operational farmer-owned MCCs were reported to have received milk from 386 farmers [Zimbabwe Dairy Industry Trust (ZDIT), 2021]. Several MCCs (e.g., Nharira and Honde Valley) have ventured into small-scale value addition producing products such as yogurts and cheese and increased their profitability (Kandjou, 2012). Otherwise, medium and large-scale (e.g., Dairibord) processors collect bulk milk from the milk collection centers and transport it to their processing factories. Smallholder farmers' contribution to the national milk pool was about 1.1 million liters (2\% of national production) in 2012. In the same year (2012), only six smallholder producer associations were reported to have produced sufficient quantities of milk to deliver to a major milk processor (Kagoro and Chatiza, 2012). In 2019, a study conducted across 60 districts in the country's ten provinces reported monthly milk production levels of 1,703,666 liters per month and 5,020,034 liters per month in the large-scale commercial sector (Transforming Zimbabwe's Dairy Value Chain for the Future Action (TranZ DVC), 2019).

Milk processing is dominated by five out of the eight registered large-scale dairy processors (see Table 1) that are processing $85 \%$ of the milk [Zimbabwe Dairy Industry Trust (ZDIT), 2021]. On the other hand, 27 registered small-scale and 12 medium-scale processors correspondingly process $8 \%$ and $2 \%$ of the milk [Zimbabwe Dairy Industry Trust (ZDIT), 2021]. Dairibord Holdings (2019), a major dairy processor in Zimbabwe, reported that about 3.4 million liters of the raw milk processed in 2019 were collected from smallholders. The increase in quantities of smallholder milk annually sold on the formal market (i.e., 1.1 million liters in 2012 to 3.4 million liters in 2019) signify progress in overall milk production (SNV, 2012). However, relative to their current annual production levels ( $\sim 20$ million liters), the amount of milk entering formal markets from smallholder and medium-scale dairy producers is still low.

\section{ENVIRONMENTAL IMPACTS}

Cattle production heavily relies on natural resources and has a substantial environmental footprint due to methane and nitrous oxide emissions from enteric fermentation and manure; ammonia loss during manure handling and storage; deforestation and biodiversity loss when clearing land for grazing; and degradation linked in review to poor pasture management, overgrazing and soil erosion (FAO, 2006b; Gerber et al., 2013). Studies on the environmental impacts of dairy production systems in Zimbabwe are limited. For example, we only found one study on greenhouse gas emissions from livestock systems in Zimbabwe. A drawback of the study was that Tier 1 (default) IPCC emission factors were used to quantify GHG
TABLE 1 | Summary of Zimbabwe milk value chain actors.

\begin{tabular}{|c|c|}
\hline Category & Main actors \\
\hline $\begin{array}{l}\text { Farmer } \\
\text { representation }\end{array}$ & $\begin{array}{l}\text { Organizations advocating for dairy farmer interests } \\
\text { include Zimbabwe Association of Dairy Farmers } \\
\text { (ZADF), Commercial Farmers Union (CFU), } \\
\text { Zimbabwe Farmers' Union (ZFU). }\end{array}$ \\
\hline $\begin{array}{l}\text { Farmer extension and } \\
\text { veterinary services }\end{array}$ & $\begin{array}{l}\text { Departments in the Ministry of Lands, Agriculture } \\
\text { and several NGOs, milk processors, }\end{array}$ \\
\hline $\begin{array}{l}\text { Research services } \\
\text { (Research Institutes, } \\
\text { NGOs and } \\
\text { Universities) }\end{array}$ & $\begin{array}{l}\text { The setting of research priorities is mainly done by } \\
\text { the Zimbabwe Dairy Industry Trust, Research } \\
\text { institutes and universities }\end{array}$ \\
\hline $\begin{array}{l}\text { Animal and milk } \\
\text { traders }\end{array}$ & Cooperatives \\
\hline Milk processors & $\begin{array}{l}\text { Dairibord Holdings, Nestle, Kefalos, Dendairy, } \\
\text { Prodairy, Kershelmar, Alpha Omega, Yomilk. }\end{array}$ \\
\hline $\begin{array}{l}\text { Input provision and } \\
\text { financial support for } \\
\text { farmers }\end{array}$ & $\begin{array}{l}\text { Private sector dealers, banks and micro-credit } \\
\text { providers. }\end{array}$ \\
\hline Regulatory services & $\begin{array}{l}\text { Government ministries and Parastatals, and civil } \\
\text { society actors }\end{array}$ \\
\hline Consumer protection & $\begin{array}{l}\text { Organizations interested in consumer interests (i.e., } \\
\text { quality and prices), including the Consumer Council } \\
\text { of Zimbabwe (CCZ) and the Standards Association } \\
\text { of Zimbabwe (SAZ) }\end{array}$ \\
\hline
\end{tabular}

emissions. These default emission factors are mainly determined using studies almost exclusively conducted in Western countries (Goopy et al., 2018), which have enormous uncertainties for African livestock systems. In the study by Svinurai et al. (2018), which covered 35 years, 58-75\% of total annual emissions from livestock were estimated from the smallholder sector. The smallholder sectors' low productivity is associated with high GHG emissions per unit of milk. A study conducted in Kenya, under similar low intake dairy production systems, shows that increased feed intake increases milk production and the total GHG emissions from enteric fermentation (Ndung'u et al., 2018). If herd sizes grow to meet the demand and reduce the milk deficit, the total GHG emissions and water use are also likely to increase. To counteract this, herd growth needs to co-occur with productivity increases to reduce GHG emissions and water use (e.g., Douxchamps et al., 2021; Hawkins et al., 2021) per liter of milk. Increased productivity has to go hand-in-hand with increased land and water productivity (more animal nutrition per area of land and liter of water) and feed efficiency (more animal product per unit of feed), to avoid clearing of more land to produce feed, and enhance milk production per unit animal, water and land, respectively. A range of resource-useefficient and climate-smart practices (e.g., forage production and conservation, water management, manure management) exist, but adoption is low due to various financial, communication and socio-economic factors (CIAT and World Bank, 2017).

Addressing productivity challenges should coincide with tackling the environmental impacts of the dairy sector. Land degradation, water scarcity and climate change should be addressed through pursuing management practices with 
environmental co-benefits. Generally, most technologies and practices that reduce GHG emissions have economic benefits as they often increase productivity (Gerber et al., 2013). In addition, Svinurai et al. (2018) showed that current livestock populations, production and emissions trends suggest that even if Zimbabwe's national livestock herd doubled in 2030, relative to 2014, methane emission intensities (per capita) would be similar to those observed in 1980. Therefore, there is potential to increase productivity and reduce the milk deficit without significantly increasing GHG emissions.

\section{KEY STAKEHOLDERS}

Several previous studies have mapped the key public, private and civil society actors along the dairy value chain (Marecha, 2009; Kagoro and Chatiza, 2012; Matekenya, 2016). Based on this already existing information, a summary of the roles different value chain actors play is presented in Table 1.

\section{BARRIERS AND CONSTRAINTS TO OPTIMAL PERFORMANCE OF THE MILK VALUE CHAIN}

It is unambiguous that the Zimbabwean dairy value chain is far from optimal performance resulting from multiple factors affecting local milk production. At the farm level, low milk yields and calving rates, late age at first calving and long calving intervals prevail and are directly related to nutritional aspects, the use of inappropriate breeds, poor farm management, limited disease control and poor extension (Smith et al., 2002; Ngongoni et al., 2006; Munangi, 2007). The already limited availability of suitable farmland and water are declining due to climate change and climate variations (Brown et al., 2012). Changing rainfall patterns, heat waves or droughts (e.g., 2015-2017) lead to poor pasture conditions, feed and forage seasonality, yield decreases and price increases (resulting in difficulties for animal breeding; Masama, 2013), and high susceptibility to pests and diseases-all having immediate adverse effects on milk yields and production costs. At the macro and value chain level, extreme climatic conditions are causing damages to infrastructure (i.e., water and energy supply), resulting in higher costs for milk cooling, disruptions in the transport of perishable goods such as milk (Chari and Ngcamu, 2017a), increased processing and transport costs, consumer prices, vulnerability and food insecurity (Chari and Ngcamu, 2019). In our view, the dairy sector requires strategic investments along the value chain to achieve its full potential, e.g., in cooling facilities, milking machines or road and transportation infrastructure. Zimbabwe, however, has high burdens (bureaucracy, complex procedures) for accessing financing (Hahlani and Garwi, 2014). In addition, credit providers are reluctant to lend money to farmers who do not possess collateral (Chari and Ngcamu, 2019); their credit rates are high (up to 14\%; Commercial Farmers Union, 2014) and more oriented toward short-term investments. Long-term investment projects, such as establishing improved forages or purchasing milking machines, cannot be readily financed under these conditions (Chari and Ngcamu, 2017b), discouraging farmers from technology adoption.

Furthermore, productive inputs are expensive in Zimbabwe, affecting the dairy value chain. For example, both the purchase of heifers and on-farm breeding are costly (Hahlani and Garwi, 2014), forage seeds are often unavailable, high labor costs reduce returns along the value chain, and electricity is expensive and frequently disrupted, boosting the use of less efficient and more expensive energy sources for production and processing (SNV, 2012). Regarding policy-based constraints, Zimbabwe was facing a phase of instability from 1998 to 2000, followed by a fast track land reform program that affected the dairy sector. Large dairy farmers lost their farms, and land titles for the resettled farmers are still unclear (Marecha, 2013), and this, combined with unresolved land disputes between farmers, leads to low longterm investments in farm improvement plans (Marecha, 2013; Chari and Ngcamu, 2017a). Compared to other countries (e.g., South Africa, Kenya), raw milk prices are substantially higher in Zimbabwe (Kawambwa et al., 2014), probably due to the described production constraints and inefficiencies (Gadzikwa, 2013). The lack of infrastructure, technologies and adequate management affect milk quantity and quality, the latter being a major bottleneck for milk processing (Chari and Ngcamu, 2019). The situation is further aggravated by limited technical assistance schemes provided to dairy farmers (Smith et al., 2002). Gender inequality is a significant constraint in the development of the dairy value chain. Men, women and youth play essential roles in the livestock sector, but the level of participation differs significantly. Although the situation is gradually changing, men continue dominating livestock production, mainly for cultural reasons, overshadowing women's ownership of livestock, decision-making and control (Chawatama et al., 2005; Daniels, 2008; Mupawaenda et al., 2009). Gender roles are based on dynamic cultural beliefs for which the pace of change is determined by increased awareness and incentives. Thus, targeted social awareness campaigns, combined with appropriate policies and incentive mechanisms, can harness the perspectives and capacities of men, women, and youth to improve value chain performance and gender equity.

\section{DISCUSSION ON KEY INTERVENTIONS TO IMPROVE THE MILK VALUE CHAIN IN ZIMBABWE}

In Table 2, we present a range of interventions to improve the performance of the dairy value chain in Zimbabwe. Briefly, the interventions are disaggregated based on value chain links. While needed interventions are primarily known, the challenge is on ensuring that the needed actions for their actual implementation are taken. Taking the needed actions is not an easy task as smallholder dairy farmers, who include many underperforming farmers, are mainly resource-constrained and, at times, located in remote areas with limited supporting infrastructure. Postland reform, the government of Zimbabwe has targeted the 
TABLE 2 | Key interventions for improving the dairy value chain in Zimbabwe.

\begin{tabular}{|c|c|}
\hline Value chain segment & Interventions \\
\hline Inputs & $\begin{array}{l}\text { - Availability and access to affordable improved forage seeds (including vegetative propagation) to increase the supply of } \\
\text { forage/forage quality } \\
\text { - Support local feed and forage seed production and seed distribution } \\
\text { - Where necessary, support local businesses that import seeds of improved grasses and feedstock that cannot be } \\
\text { produced locally due to physiological constraints } \\
\text { - Accelerate the speed of input importation and the registration of new varieties } \\
\text { - Feed conservation and associated business models } \\
\text { - Access to regular and uninterrupted energy and water supplies } \\
\text { - Installation of irrigation infrastructure } \\
\text { - community-based animal health services, para-extension and artificial insemination }\end{array}$ \\
\hline Production & $\begin{array}{l}\text { - Improved availability of and access to in-calf heifers } \\
\text { - Development of formal dairy training centers } \\
\text { - managroved mechanization of dairy systems for improving efficiency in feed production, feed processing, cattle } \\
\text { - Adoption of cattle breeds with high milk production potential (which need to go hand in hand with): } \\
\text { - Good on-farm feed and animal management practices } \\
\text { - Appropriate animal health measures } \\
\text { - Harmonization of efforts and concepts and training of technical assistants/extensionists among government agencies } \\
\text { and NGOs }\end{array}$ \\
\hline Processing & $\begin{array}{l}\text { - Set up and rehabilitate processing infrastructure and quality assurance systems } \\
\text { - Increase number of technical experts and their availability } \\
\text { - Improve extension/training and access to inputs required for milk processing and value addition (e.g., cheese and } \\
\text { yogurt production) }\end{array}$ \\
\hline Distribution and marketing & $\begin{array}{l}\text { - Improved distribution infrastructure (e.g., milk collection centers, road infrastructure) } \\
\text { - Improve farmer access to information (e.g. price information systems; information fora, multi-actor platforms) } \\
\text { - Support more collective actions, e.g., cooperatives, bulking of milk and guaranteed prices }\end{array}$ \\
\hline Consumers & $\begin{array}{l}\text { - Product differentiation and niche markets (e.g., denominated origin, quality attributes, environmental attributes, fair } \\
\text { trade, animal welfare) } \\
\text { - Consumer awareness campaigns on milk and milk products } \\
\text { - Increase consumer promotional material }\end{array}$ \\
\hline Financing & $\begin{array}{l}\text { - Easy access to financing programs } \\
\text { - Risk insurance } \\
\text { - Affordable credit and general credit accessibility; credit lines for sustainable intensification efforts } \\
\text { - International assistance, e.g., necessary assistance vs. reduction of dependence } \\
\text { - Strengthening safety nets } \\
\text { - Training on investment prioritization }\end{array}$ \\
\hline Entrepreneurial support & $\begin{array}{l}\text { - Local transformation and formalization } \\
\text { - Increased number of local value addition and milk transformation plants (e.g., cheese, milk, yogurts) } \\
\text { - Support of inclusive business models }\end{array}$ \\
\hline Institutional, policy and regulatory support & $\begin{array}{l}\text { - Better institutional coordination among value chain actors } \\
\text { - Evidence-based policy support/legislation }\end{array}$ \\
\hline Cross-cutting & $\begin{array}{l}\text { - Women and youth empowerment (i.e., increasing women involvement in the dairy value chain) } \\
\text { - Design interventions in the dairy value chain to allow women to change their lives (production of milk-based products } \\
\text { - Strengthening collaboration among direct value chain actors but also with value chain framework } \\
\text { - Access to in-depth education on the dairy industry (from a young age) } \\
\text { - Organization and Training/capacity-building of Dairy farmers }\end{array}$ \\
\hline
\end{tabular}

dairy industry in its vision of transforming the nation into a middle-income country by 2030 . Therefore, there have been several efforts to resuscitate the local dairy industry. For instance, in 2017, the government launched the Dairy Revitalisation
Programme funded in review through the Dairy Resuscitation Fund and aimed to increase national production to 200 million liters per year by 2025. Also, in 2019, supported by the E.U., the government launched the Zimbabwe Agricultural Growth 
Programme (ZAGP) to address weaknesses and gaps in livestock value chains. This programme aims to increase investments, propose institutional reforms and policy alignment to support the dairy sector [Zimbabwe Agricultural Growth Programme (ZAGP), 2019]. However, over-reliance on external funding to revive the dairy sector may not be a sustainable solution; shifting to more local and continuous investments may be a more prudent approach (Washaya and Chifamba, 2018). The Zimbabwean diaspora, estimated at four million [International Organization for Migration (IOM), 2015], presents a vast potential source of capital investment in the dairy sector (Madziva et al., 2018). However, the government may need to highlight challenges and investment opportunities along the dairy value chain, create proper incentives, and develop regulatory mechanisms to protect investments. In addition, by creating spaces for national discussions, including the diaspora, the country could also tap into their experiences and expertise to innovate along the dairy value chain.

It would be strategic for the public and private sector to increase research investments tailored to generate knowledge on technologies and practices that result in efficiency gains along the dairy value chain. For instance, due to high costs for feed, limited access to affordable finance and insecure land holdings, most farms have dairy animal herds below their potential [Zimbabwe Dairy Industry Trust (ZDIT), 2021]. Therefore, besides focusing on efficiency gains along the dairy value chain, investments need to increase the dairy herd in smallholder and mediumscale farms. For example, smallholder farmers with an average of 3 cows per farm (Kagoro and Chatiza, 2012), with each cow producing 5 liters per day (Chinogaramombe et al., 2008). Even if the average milk productivity per cow were to match the higher end of cows on large-scale farms (25 liters per day; Matekenya, 2016), their production levels would remain small-scale $(<200$ liters per farm per day). Therefore, to transition from a small to a medium-scale or a large-scale dairy producer, the initial focus should be on increasing dairy herd sizes per farm.

After increasing the dairy herd per farm, the next step would be to find creative, feasible and context based-solutions to overcome the low and seasonal supply of high-quality animal feed. Improved feed availability could be done by introducing and promoting improved forages tolerant to abiotic (excess and scarcity of water) and biotic (pest and diseases) stresses as the basis of feeding. Although the planting of improved forages is considered to be scale-neutral, meaning that the technology can be used by smallholders as well as medium- to largescale producers, the private forage seed suppliers estimate that mostly smallholder to medium-scale livestock producers adopt them to sustainably intensify their production systems (Labarta et al., 2017; Fuglie et al., 2021). Forages compete less with human nutrition, e.g., grain crops, and have the co-benefit of maintaining soil fertility, enhancing carbon accumulation and improving GHG balances and Water-Use-Efficiency. However, this would require functional seed systems, ensuring seed availability, accessibility, and affordability (Peters et al., 2021).

With appropriate training and the proper incentive mechanisms, the estimated $8 \%$ of youth unemployed (World Bank, 2021) can be engaged to co-explore solutions to improve on-farm productivity. For instance, in the case of improving feed supply, a practical solution could be for the youth to receive support for establishing local seed supply systems (i.e., for forage legumes). The local seed supply systems could improve dairy farmers access to affordable, high-quality seed to sow on their private or communally owned pasturelands. This forage-based basal diet can be complemented by strategic supplementation with several crops grown in the rural areas (i.e., maize, groundnut, sunflower, pearl millet, sorghum and cowpea). Dependence on local crops presents farmers with an opportunity for cost-effective feed-level interventions that can improve market competitiveness and productivity of their systems (Murungweni et al., 2004; Ngongoni et al., 2006; Gusha et al., 2013; Mashanda, 2014; Gwiriri et al., 2016; Chifamba et al., 2018). To overcome periods of feed scarcity, high-quality forages and feed crops could also be conserved as hay or silage and become the basis of densified feeds; densification may allow an easier transfer from one region to another (Dey et al., 2021, unpublished).

Youth could establish feed processing businesses based on high-quality feed mixes based on local grains to provide dairy farmers with local high-value supplements or concentrates (Chifamba et al., 2018). We expect local sourcing to reduce feed costs and increase the profitability of dairy operations. In addition, youth can be trained as para-extension agents that can support artificial insemination programmes to improve the local breeds and veterinary services to support animal health (Kagoro and Chatiza, 2012). The engagement of youth (as local entrepreneurs) to supply improved seeds, deliver animal health services and improve cattle breeds will contribute to employment creation and the intake of quality feed by healthy and high yielding cattle breeds and ultimately improve milk supply and quality from smallholder and medium-scale dairy producers. Youth participation in the local economy may also prevent their migration to crowded urban areas.

Mhlanga et al. (2018) projected that without a global reduction in atmospheric $\mathrm{CO}_{2}$ concentrations and the resultant high air temperatures would reduce feed availability and the area suitable for dairy farming and have devastating impacts on the local dairy industry. To maintain milk yield stability even during dry periods, dairy farmers may need to consider drought-tolerant forage crops that better use available moisture. One example of this is Cactus pear (Opuntia spp.), which efficiently converts water into dry matter (Galizzi et al., 2004). Opuntia species are known for developing physiological, phenological and structural adaptations (Guevara et al., 2011), making them productive in these drier environments (Nobel and Zutta, 2008). On average, the biomass production from cactus per unit of water is about three times as high as with C4 plants and five times as high as with C3 plants (Snyman, 2013), making Opuntia cladodes a valuable option for successfully balancing parts of the cattle diet (Einkamerer et al., 2009; de Waal et al., 2013). From a well-managed cactus pear plantation of 800 to 1000 plants/ha, around $10 \mathrm{t} / \mathrm{ha}$ cladode dry matter and $20 \mathrm{t} / \mathrm{ha}$ fruit biomass can be obtained, but values vary with genotype (Fouché and Coetzer, 2013). To improve the adoption of Opuntia, investments are needed in research and awareness-raising on its use and 
potential benefits. In addition, investments in technical support for establishing fodder banks with Opuntia, could stimulate its adoption as a feed option during dry and drought periods (Makumbe, 2010).

The smartphone penetration rate is 52 per 100 inhabitants ( 7.7 million users) (Econet Wireless Zimbabwe, 2020). However, considering that several inhabitants may have more than one smartphone, while the exact number of smartphone users is uncertain, it is probably lower than 52\%. On the other hand, mobile subscriptions are very high (90 per 100 inhabitants; $\sim 13$ million subscribers) (ITU, 2021). To support the complete transition toward digital agriculture, government and private sector actors need to innovate and improve smartphone affordability and reduce the cost of mobile data. These actions may incentivize the adoption of digital tools that will have cascading benefits across the dairy value chain. For instance, tools like smartphone applications and online platforms can help connect dairy value chain stakeholders and improve farmer participation, actor coordination, and information flow across the value chain. Other benefits include reducing the length of the value chain (by avoiding unnecessary intermediaries and associated costs), improving milk traceability and monitoring milk quality, using digital records to apply for credit, supporting decision-making, and optimizing farm operations (Born et al., 2020).

\section{CONCLUSIONS}

Several previous studies and reports have presented what needs to be done by the different actors to create a sustainable and inclusive dairy value chain, yet progress remains limited. While there are certainly no silver bullets, actions that support improved performance at different value chain stages are needed. Moreover, increased productivity in the dairy sector could return Zimbabwe to being a net exporter of dairy products and contribute toward meeting the ambitious national goal of transforming the nation into a middle-income country within a decade (by 2030). In our opinion, to sustainably solve challenges along the dairy value chain, more attention should be placed on the underperforming smallholder and medium-scale dairy farmers and supporting

\section{REFERENCES}

Born, L., Chirinda, N., Mabaya, E., Afun-Ogidan, O., Girvetz, E., Jarvis, A., et al. (2020). Digital Agriculture Profile, South Africa. FAO. Available online at: http:// www.fao.org/3/cb2506en/CB2506EN.pdf (accessed June 15, 2021).

Brown, D., Chanakira, R., Chatiza, K., Dhliwayo, M., Dodman, D., Masiiwa, M., et al. (2012). Climate Change Impacts, Vulnerability and Adaptation in Zimbabwe. IIED Climate Change Working Paper No. 3. Available online at: https://pubs.iied.org/sites/default/files/pdfs/migrate/10034IIED.pdf (accessed October, 2012).

Chari, F., and Ngcamu, B. S. (2017b). The impact of collaborative strategies on disaster risk reduction in Zimbabwe dairy supply chains in 2016. J. Transdiscip. Res. Southern Africa 13:a433. doi: 10.4102/td.v13i1.433

Chari, F., and Ngcamu, S. B. (2017a). An assessment of the impact of disaster risks on dairy supply chain performance in Zimbabwe. Cogent Eng. 4:1. doi: 10.1080/23311916.2017.1409389

Chari, F., and Ngcamu, S. B. (2019). "A synthesis of risks in dairy value chains in Southern Africa: cases of South Africa and Zimbabwe," in Current Issues and value-chain interventions that creatively balance investments, livelihoods, and profits within the local context.

\section{DATA AVAILABILITY STATEMENT}

The original contributions presented in the study are included in the article/supplementary material, further inquiries can be directed to the corresponding author/s.

\section{AUTHOR CONTRIBUTIONS}

The introduction was written by NC, AW, and CM. The sections on milk production regions and production systems and milk markets were written by CM, JN, and AT. The section on environmental impacts was written by AN, MP, and NC. The section on key stakeholders was written by AW, CM, AT, and NC. The section on barriers and constraints to optimal performance of the milk value chain was written by SB, MP, AN, and AT. The discussions on key interventions to improve the milk value chain in Zimbabwe and conclusions were written by all the authors. All authors contributed to the article and approved the submitted version.

\section{FUNDING}

This work was funded by the CGIAR Research Program on Livestock. The funders had no role in the design of the study; in the collection, analyses, or interpretation of data; in the writing of the manuscript, or in the decision to publish the results.

\section{ACKNOWLEDGMENTS}

This work was carried out as part of the CGIAR Research Program on Livestock. We thank all donors who globally support our work through their contributions to the CGIAR System. CGIAR is a global research partnership for a food-secure future. Its science is carried out by 15 Research Centers in close collaboration with hundreds of partners across the globe.
Challenges in the Dairy Industry, eds S. A. Ibrahim, T. Zimmerman, and R. Gyawali. London: IntechOpen.

Chawatama, S., Mutisi, C., and Mupawaenda, A. C. (2005). The socio-economic status of smallholder livestock production in Zimbabwe: a diagnostic study. Livestock Res. Rural Dev. 17, 1-2. Available online at: http://www.lrrd.org/ lrrd17/12/chaw1714.html (accessed June 15, 2021).

Chifamba, E., Ngongoni, T. N., Nyanga, L. K., Nyagura, S., and Maasdrop, B. (2018). Effect of mixed maize-legume silages on milk quality and quantity from lactating smallholder dairy cows. Trop. Anim. Health Prod. 50, 1255-1260. doi: 10.1007/s11250-018-1552-4

Chinogaramombe, G. N. C., Muchenje, V., Mapiye, C., Ndlovu, T., Chimonyo, N., and Musemwa, L. (2008). Challenges for improving smallholder dairy production in the semiarid areas of Zimbabwe. Livestock Res. Rural Dev. 20:34. Available online at: http://www.lrrd.org/lrrd20/3/chin20034.html (accessed June 15, 2021).

CIAT and World Bank (2017). Climate-Smart Agriculture in Zimbabwe. CSA Country Profiles for Africa Series. Washington, DC: International Center for Tropical Agriculture (CIAT). 
Commercial Farmers Union (2014). "Zimbabwean agriculture within an African global context," in 71st Annual Congress Report. Available online at: http://www. cfuzim.org/ cfuzimb/images/brochure2014.pdf (accessed October 28, 2014).

Dairibord Holdings (2019). Annual Report. Available online at: https://www. dairibord.com/wp-content/uploads/2020/09/DAIRIBORD-HOLDINGSLIMITED-2019-ANNUAL-REPORT-FINAL.pdf (accessed May 14, 2021).

Dairy Services (2020). Dairy Services Unit Annual Report 2020. Harare, Zimbabwe: Department of Veterinary Services.

Daniels, R. C. (2008). Gender dimensions to the incidence of tariff liberalization. Afric. Dev. Rev. 201, 67-93. doi: 10.1111/j.1467-8268.2008.00177.x

de Waal, H. O., Combrinck, W. J., and Fouché, H. J. (2013). "Preserving masked cactus pear (Opuntia ficus-indica) fruit with wheat straw, maize hay or lucerne hay," in Paper presented at the VIII International Congress on Cactus Pear and Cochineal, 28-31 October 2013, Palermo, Italy.

Dey, B., Notenbaert, A., Makkar, H., Mwendia, S., Sahlu, Y., and Peters, M. (2021) Realizing Economic and Environmental Gains from Cultivated Forages and Feed Reserves in Ethiopia. Unpublished manuscript.

Douxchamps, S., Notenbaert, A., Cardoso, J. A., Romero, M., and Peters, M. (2021) "The role of improved forages in solving the water scarcity issue of 4 billion people," in Poster prepared for The International Grassland and International Rangeland Kenya 2021 Virtual Congress, 25-29 October 2021. Cali (Colombia): Alliance of Bioversity and CIAT.

Econet Wireless Zimbabwe (2020). Annual Report. Available online at: https:// news.ewzinvestor.com/?news_id=78020 (accessed May 13, 2021).

Einkamerer, O. B., de Waal, H. O., Combrinck, W. J., and Fair, M. D. (2009). Feed utilization and growth of Dorper wethers on Opuntia-based diets. South Afric. J. Anim. Sci. 39, 53-57. doi: 10.4314/sajas.v39i1.61178

FAO (2006a). Fertilizer Use by Crop in Zimbabwe. Rome: Food and Agriculture Organization of the United Nations. Available online at: https://www.fao.org/ 3/a0395e/a0395e00.htm (accessed June 15, 2021).

FAO (2006b). Livestock's Long Shadow-Environmental Issues and Options, eds H. Steinfeld, P. J. Gerber, T. Wassenaar, V. Castel, M. Rosales and C. de Haan. Rome: FAO. Available online at: https://www.fao.org/3/a0701e/a0701e00.htm (accessed June 15, 2021).

FAO (2021). Zimbabwe at a Glance. Available online at: http://www.fao. org/zimbabwe/fao-in-zimbabwe/zimbabwe-at-a-glance/en/ (accessed June 15, 2021).

Fouché, H. J., and Coetzer, G. M. (2013). "Response of cactus pear (Opuntia spp.) biomass production to fruit load," in Paper presented at the VIII International Congress on Cactus Pear and Cochineal, 28-31 October 2013, Palermo, Italy.

Fuglie, K., Peters, M., and Burkart, S. (2021) The extent and economic significance of cultivated forage crops in developing countries. Front. Sustain. Food Syst. 5:712136. doi: 10.3389/fsufs.2021.712136

Gadzikwa, E. C. (2013). "The future of the manufacturing sector in Zimbabwe," in Institute of Chartered Accountants of Zimbabwe Congress, 18-20 July 2013, Victoria Falls. Available onine at: https://www.icaz.org.zw/iMISDocs/ manufacture.pdf (accessed June 15, 2021).

Galizzi, F. A., Felker, P., González, C., and Gardiner, D. (2004). Correlations between soil and cladode nutrient concentrations and fruit yield and quality in cactus pears, Opuntia ficus-indica in a traditional farm setting in Argentina. J. Arid Environ. 59, 115-132. doi: 10.1016/j.jaridenv.2004.01.015

Gerber, P. J., Steinfeld, H., Henderson, B., Mottet, A., Opio, C., Dijkman, J., et al. (2013). Tackling Climate Change Through Livestock-A Global Assessment of Emissions and Mitigation Opportunities. Rome: Food and Agriculture Organization of the United Nations (FAO).

Goopy, J. P., Onyango, A. A., Dickhoefer, U., and Butterbach-Bahl, K. (2018). A new approach for improving emission factors for enteric methane emissions of cattle in smallholder systems of East Africa-results for Nyando, Western Kenya. Agric. Syst. 161, 72-80. doi: 10.1016/j.agsy.2017. 12.004

Government of Zimbabwe (GoZ). (2013). Ministry of Agriculture, Mechanization and Irrigation Development Agricultural Sector Gender Assessment Report. Harare: GoZ.

Guevara, J. C., Felker, P., Balzarini, M. G., Páez, S. A., Estevez, O. R., Páez, M. N., et al. (2011). Productivity, cold hardiness and forage quality of spineless progeny of the Opuntia ficus indica $1281 \times$ O. lindheimerii 1250 cross in Mendoza plain, Argentina. J. Profess. Assoc. Cactus Dev. 13, 47-61. Available online at: https://jpacd.net/jpacd/article/view/88 (accessed June 15, 2021).
Gusha, J., Manyuchi, C. R., Imbayarwo-Chikosi, V. E., Hamandishe, V. R., Katsande, S., and Zvinorova, P. I. (2013). Production and economic performance of F1-crossbred dairy cattle fed non-conventional protein supplements in Zimbabwe. Trop. Anim. Health Prod. 46, 1257-1263. doi: 10.1007/s11250-0130481-5

Gwiriri, L. C., Manyawu, G., Mashanda, P. B., Chakoma, I., Moyo, S., Chakoma, C., et al. (2016). The potential of replacing conventional dairy supplements with forage legume-based diets in Zimbabwe's smallholder dairy sector. Afric. J. Range Forage Sci. 33, 155-163. doi: 10.2989/10220119.2016.11 70727

Hahlani, C. D., and Garwi, J. (2014). Operational challenges to small dairy farming: the case of maryfield dairy settlement scheme in Chipinge District of Zimbabwe. IOSR J. Human. Social Sci. 19, 87-94. Available online at: https://iosrjournals.org/iosr-jhss/papers/Vol19-issue1/Version-4/ P019148794.pdf?id=8729 (accessed June 15, 2021).

Hanyani-Mlambo, B. T. (2000). Smallholder Dairy Production and Marketing in Zimbabwe: A Socio-Economic Study of the Gokwe, Rusitu and Marirangwe Dairy Development Projects. Working Paper, AEE 3/2000 Department of Agricultural Economics and Extension, University of Zimbabwe, Harare.

Hawkins, J., Yesuf, G., Zijlstra, M., Schoneveld, G. C., and Rufino, M. C. (2021). Feeding efficiency gains can increase the greenhouse gas mitigation potential of the Tanzanian dairy sector. Sci. Rep. 11:4190. doi: 10.1038/s41598-021-8 $3475-8$

International Organization for Migration (IOM) (2015). IOM Zimbabwe Strategic plan 2015-2018. Available online at: https://zimbabwe.iom.int/sites/zimbabwe/ files/Docs/IOM\%20Zimbabwe\%20Strategic\%20Plan.pdf (accessed May 16, 2021).

ITU (2021) Available online at: https://www.itu.int/en/ITU-D/Statistics/Pages/ stat/default.asp (accessed May 13, 2021).

Kagoro, J. M., and Chatiza, K. (2012). Zimbabwe's Dairy Subsector Study. Harare: SNV Country Office.

Kandjou, M. J. (2012) Technical challenges and Agribusiness prospects for developing pro-poor small scale dairy processing schemes in Omaheke Region on Namibia: Lessons from Zimbabwe's Dairy Development Program (Ph.D thesis). University of Zimbabwe. Available online at: http://www.library.uz.ac.zw/handle/10646/ 773

Kashagura, C. (2014). "Policy issues for possible temporal and spatial rainfall distribution changes due to climate change," in Conference Proceedings: Water Forum on Water Security and Water-related Disaster Challenges: Policy Issues for Discussion.

Kawambwa, P., Hendriksen, G., Zandonda, E., and Wanga, L. (2014). Business Viability Assessment Study of Smallholder Dairy Farming in Zambia. Wageningen: Alterra. Available online at: https://agriprofocus.com/upload/ Business_Viability_assessment_study_of_small_holder_dairy_farming_in Zambia1425011596.pdf (accessed June 15, 2021).

Labarta, R., Martinez, J. M., Yaccelga, A., Reyes, B., Gomez, L., Maredia, M., et al.(2017). Assessing the Adoption and Economic and Environmental Impacts of Brachiaria Grass Forage Cultivars in Latin America Focusing in the Experience of Colombia SPIA Technical Report. Rome, Italy: Standing Panel for Impact Assessment (SPIA).

Madziva, R., Siwale, J., and Thondhlana, J. (2018). "Exploring gender and diaspora investment among diaspora women in the U.K." in African Diaspora Direct Investment (Cham, Palgrave Macmillan), 211-37.

Makumbe, M. T. (2010). "A review of the distribution, use and potential of cactus pear (Opuntia ficus-indica (L.) Mill.) as ruminant feed in Zimbabwe," in Improved Utilization of Cactus Pear for Food, Feed, Soil and Water Conservation and Other Products in Africa. Proceedings of International Workshop, Mekelle (Ethiopia), 19-21 October 2009, eds A. Nefzaoui, P. Inglese, and T. Belay, p. 36-42.

Mandiwanza, A. S. (2007). "The current state of the dairy industry in Zimbabwe," in Proceedings, National Dairy Symposium on Reviving the Zimbabwe Dairy Industry, Harare, Zimbabwe.

Marecha, T. C. (2009). An Explorative Study of Raw Milk Chains in Zimbabwe. A Case Study of Seke District. Leeuwarden: Van Hall Larenstein

Marecha, T. C. (2013). "A case study of the Zimbabwe dairy industry," in SADC Stakeholders Sanitary and Phytosanitary Awareness Workshop (Presentation), Pretoria, 12-13 September 2013 
Marongwe, N., Made, J. M., Dengu, E., Mukahanana, M., Vhudzijena, V., and Moyo, M. (1998) "Land Resources," in The State of Zimbabwe's Environment 1998, eds M. Chenje, L. Sola and D. Paleczny. Harare: Government of the Republic of Zimbabwe, Ministry of Mines, Environment and Tourism.

Masama, E. (2013). Research note: Impact of climate change on livestock production in Zimbabwe. Int Open Dist Learn J. (2013) 2, 47-53. Available online at: https://www.zimagrihub.org.zw/sites/default/files/documents/ Resaerch\%20note\%20Impact\%20of\%20climate\%20change\%20on\%20livestock \%20production.pdf (accessed June 15, 2021).

Mashanda, P. (2014). Potential of Mucuna pruriens and Vigna unguiculata as Replacement Feed for Commercial Concentrates in a Smallholder Dairy Enterprise. MSc thesis, University of Zimbabwe, Harare, Zimbabwe.

Matekenya, D. T. (2016). "Large scale dairy value chain in Zimbabwe," in A paper presented to the division of Livestock Research DRandSS.

Mhlanga, I., Ndaimani, H., Mpakairi, K., and Mujere, N. (2018). Climate change: an uncertain future for dairy farming in Zimbabwe. Trans. R. Soc. South Africa. 73, 237-242. doi: 10.1080/0035919X.2018.1503203

Ministry of Lands, Agriculture and Rural Resettlement (2016). Overview of Zimbabwe's Dairy Industry. Available online at: http://www.agriculture.gov. zw/phlmbeta/index.php/commodities/90-commodities/dairy/119-dairyindustry-overview (accessed 15 June 2021).

Mugandani, R., Wuta, M., Makarau, A., and Chipindu, B. (2012). Re-classification of agro-ecological regions of Zimbabwe in conformity with climate variability and change. Afric. Crop Sci. J. 20, 361-369. Available online at: https://hdl. handle.net/1807/47599 (accessed June 15, 2021).

Munangi, W. (2007). "Strategies for improving the contribution of smallholder dairy sector to supply milk in Zimbabwe," in Proceedings, National Dairy Symposium on Reviving the Zimbabwe Dairy Industry, 5-6 July 2007. Harare, Zimbabwe.

Mupawaenda, A. C., Chawatama, S., and Muvavarirwa, P. (2009). Gender issues in livestock production: a case study of Zimbabwe. Trop. Anim. Health Prod. 41, 1017-1021. doi: 10.1007/s11250-008-9268-5

Murungweni, E. C., Mabuku, O., and Manyawu, G. J. (2004).” Mucuna, lablab and paprika calyx as substitutes for commercial protein sources used in dairy and pen-fattening diets by smallholder farmers of Zimbabwe," in: Tropical Legumes for Sustainable Farming Systems in southern Africa and Australia. ACIAR Proceedings no. 115, eds A. M. Whitbread and B. C. Pengelly (Canberra: Australian Centre for International Agricultural Research), 126-135

Mzumara, M. (2012). An overview of Zimbabwe's macroeconomic environment. Int. J. Econ. Res. v3i1, 33-69. Available online at: http://www.ijeronline.com/documents/volumes/ vollissue1/Vol\%203\%20issue\%201/ijer20120301JF(4).pdf (accessed June 15, 2021).

Ndung'u, P., Bebe, B. O., Ondiek, J. O., Butterbach-Bahl, K., Merbold, L., and Goopy, J. P. (2018). Improved region-specific emission factors for enteric methane emissions from cattle in smallholder mixed crop: livestock systems of Nandi County, Kenya. Anim. Prod. Sci. 59, 1136-1146. doi: 10.1071/AN17809

Ngongoni, N. T., Mapiye, C., Mwale, M., and Mupeta, B. (2006). Factors affecting milk production in the smallholder dairy sector of Zimbabwe. Livestock Res. Rural Dev. 18, 1-21. Available online at: https://www.lrrd.cipav.org.co/lrrd18/ 6/ngon18089.htm\#: :text=The\%20poor\%20performance\%20of\%20cows, limiting\%20in\%20the\%20smallholder\%20sector (accessed June 15, 2021).

Nobel, P. S., and Zutta, B. R. (2008). Temperature tolerances for stems and roots of two cultivated cacti, Napalea cochinillifera and Opuntia robusta: acclimation, light, and drought. J. Arid Environ. 72, 633-642. doi: 10.1016/j.jaridenv.2007.08.005

Peters, M., Mwendia, S., Arango, J., Urrea-Benítez, J. L., and Ohmstedt, U. (2021). Connecting Formal and Informal Systems for Forage Crop Improvement and Scaling. Nairobi (Kenya): Alliance of Bioversity International and CIAT.
Available online at: https://hdl.handle.net/10568/113619 (accessed June 15, 2021).

Smith, T., Moyo, S., Richards, J. I., and Morton, J. F. (2002). The Role of Indigenous and Cross-Bred Cattle for Smallholder Dairy Production in Zimbabwe. Harare: UADY.

SNV (2012). Evaluation of Smallholder Dairy Programmes in Zimbabwe, Final Report. Available online at: https://snv.org/cms/sites/default/files/explore/ download/an_evaluation_of_smallholder_dairy_production_in_zimbabwe. pdf (accessed 15 June 2021).

Snyman, H. A. (2013). Growth rate and water-use efficiency of cactus pear Opuntia ficus-indica and O. robusta. Arid Land Res. Manag. 27, 337-348. doi: 10.1080/15324982.2013.771232

Svinurai, W., Mapanda, F., Sithole, D., Moyo, E. N., Ndidzano, K., et al. (2018). Enteric methane emissions and their response to agroecological and livestock production systems dynamics in Zimbabwe. Sci. Total Environ. 616-617:710-719. doi: 10.1016/j.scitotenv.2017. 10.257

Transforming Zimbabwe's Dairy Value Chain for the Future Action (TranZ DVC) (2019). Baseline Report: August 2019. Borrowdale: The Zimbabwe Agricultural Growth Programme (ZAGP). Available online at: http://zagp.org.zw/

TrendEconomy (2020). Zimbabwe Imports and Exports. Available online at: https://trendeconomy.com/data (accessed May 14, 2021).

Washaya, S., and Chifamba, E. (2018). Smallholder dairy farming: a solution to low milk production in Zimbabwe. Dairy Vet Sci J. 8:555735. doi: 10.19080/JDVS.2018.08.555735

World Bank (2021). World Development Indicators. Available online at: https://databank.worldbank.org/reports.aspx?source=world-developmentindicators\# (accessed June 15, 2021).

Zimbabwe Agricultural Growth Programme (ZAGP) (2019). Available online at: http://zagp.org.zw/Content/Uploads/ZAGP_Profile.pdf (accessed June 15, 2021).

Zimbabwe Dairy Industry Trust (ZDIT) (2021). Dairy Sector Strategic Plan for improved performance of the Dairy Value Chain in Zimbabwe 2021-2025. Harare, Zimbabwe: ZDIT.

Author Disclaimer: The views expressed in this document may not be taken as the official views of these organizations.

Conflict of Interest: The authors declare that the research was conducted in the absence of any commercial or financial relationships that could be construed as a potential conflict of interest.

The handling editor is currently editing co-organizing a Research Topic with several of the authors $\mathrm{AN}, \mathrm{SB}, \mathrm{NC}$, and $\mathrm{MP}$ and confirms the absence of any other collaboration.

Publisher's Note: All claims expressed in this article are solely those of the authors and do not necessarily represent those of their affiliated organizations, or those of the publisher, the editors and the reviewers. Any product that may be evaluated in this article, or claim that may be made by its manufacturer, is not guaranteed or endorsed by the publisher.

Copyright (c) 2021 Chirinda, Murungweni, Waniwa, Nyamangara, Tangi, Peters, Notenbaert and Burkart. This is an open-access article distributed under the terms of the Creative Commons Attribution License (CC BY). The use, distribution or reproduction in other forums is permitted, provided the original author(s) and the copyright owner(s) are credited and that the original publication in this journal is cited, in accordance with accepted academic practice. No use, distribution or reproduction is permitted which does not comply with these terms. 